\title{
Raised pro-inflammatory cytokines interleukin 6 and tumour necrosis factor $\alpha$ in coeliac disease mucosa detected by immunohistochemistry
}

\author{
R T Przemioslo, M Kontakou, V Nobili, P J Ciclitira
}

\begin{abstract}
The levels of two pro-inflammatory cytokines, interleukin 6 (IL-6) and tumour necrosis factor alpha (TNF- $\alpha$ ), in coeliac disease were studied by immunohistochemistry. Jejunal biopsy specimens from patients with untreated disease, $(n=11)$, treated disease $(n=9)$, and normal controls, $(n=11)$ were stained to detect IL-6, TNF- $\alpha$, CD45 (pan-leukocyte), and CD68 (macrophage surface antigen). Positive cells were identified in the epithelium (per 100 enterocytes) and in the lamina propria (per unit area). There was a significant increase in median IL-6 and TNF- $\alpha$ staining in both the lamina propria and the epithelium of untreated coeliac disease patients (lamina propria, 16.2 and 13.0 respectively; epithelium, 0.86 and 1.21 , all $p<0.05$ ) when compared with treated coeliac disease patients (lamina propria; 6.0 and 6.2 , epithelium; 0.60 and 0.60 ) and controls (lamina propria; 6.5 and 7.5 , epithelium; 0.58 and 0.60 ). A significant increase in the number of CD45 positive cells was found in the untreated coeliac disease lamina propria and epithelium $(p<0.05)$ but this was accompanied by a significant rise in $\mathrm{CD68}$ positive cells in the lamina propria only $(p<0 \cdot 05)$. Increased IL-6 and TNF- $\alpha$ in the lamina propria and epithelium of patients with untreated coeliac disease further supports their role in the immune pathogenesis of this disorder.

(Gut 1994; 35: 1398-1403)
\end{abstract}

Coeliac disease is an inflammatory enteropathy in which the mucosal lesions of villous atrophy and crypt cell hyperplasia improve on withdrawal of dietary gluten. The lesions seen in coeliac disease resemble those found in animal models of intestinal cell mediated hypersensitivity. ${ }^{1-3}$ There is increasing evidence to support the view that this disorder is caused by a $T$ cell mediated hypersensitivity reaction to some cereal antigens, and the characteristic lesion is partly caused by the subsequent release of abnormal amounts of proinflammatory cytokines. ${ }^{4-6}$ The cytokines interleukin 6 (IL-6) and tumour necrosis factor alpha $(T N F-\alpha)$ are secreted predominantly by activated macrophages, and to a lesser extent by $T$ helper lymphocytes. ${ }^{7}$ Together with interleukin 1, these interact to play a central part in the complicated cytokine network. The most important effects of IL-6 are in the generation of the acute phase response ${ }^{8}$; the differentiation of B lymphocytes into immunoglobulin producing cells ${ }^{9}$; and $\mathrm{T}$ cell activation, proliferation, and differentiation. 1011 TNF- $\alpha$ produces upregulation of HLA class II expression on epithelial cells and macrophages, ${ }^{12}$ adhesion molecule expression, ${ }^{13}$ chemotaxis, ${ }^{14}$ and $\mathrm{T}$ cell proliferation. ${ }^{15}$ In addition to being directly toxic to intestinal epithelial tissue, ${ }^{16}$ it is involved in reactive oxygen intermediate production. ${ }^{17}$ These effects are important steps in the propagation of a $\mathrm{T}$ lymphocyte driven immune response. We therefore wished to study the site and level of expression of the cytokines IL-6 and $T N F-\alpha$ in coeliac disease small intestinal mucosa and their role in the pathogenesis of this disorder. This may allow a better understanding of the development of the changes in the small intestinal villous architecture seen in untreated coeliac disease.

\section{Methods}

PATIENTS

The groups comprised the following patients:

\section{Untreated coeliac disease patients}

Eleven adult patients (seven women, four men, mean age 41.5 years, age range 28-64) who had been investigated and found to have pathological changes in small intestinal biopsy specimens consistent with a diagnosis of coeliac disease which later improved after at least six months' treatment with a gluten free diet (according to the European Society for Paediatric Gastroenterology criteria ${ }^{18}$ ).

Treated coeliac disease patients

Nine adult patients (six women, three men, mean age $44 \cdot 7$ years, age range $36-58$ years) with coeliac disease who had taken a gluten free diet for at least six months and who had normal small intestinal histology on haematoxylin and eosin staining.

\section{Control group}

Eleven adult patients (seven women and four men, mean age 39.7 years, age range 22-59 years) who had undergone small intestinal biopsy in the course of routine diagnostic investigation and whose villous architecture 
was normal after haematoxylin and eosin staining. All these patients were diagnosed as suffering from the irritable bowel syndrome.

\section{BIOPSY SPECIMENS}

Biopsy specimens were obtained with a peroral suction jejunal biopsy capsule. The specimens were orientated villous side uppermost and were immediately frozen in Optimum Cutting Compound (Cryo-M-Bed, Huntingdon, UK) in thawing isopentane over liquid nitrogen and stored at $-70^{\circ} \mathrm{C}$. Sections were cut to $5 \mu \mathrm{m}$ onto glass slides using a Bright Open Top Cryostat.

\section{STAINING OF TISSUES}

Sequential sections were stained using an indirect immunoperoxidase technique. Sections were fixed in acetone and then preincubated with rabbit anti-human serum (Dako A206) for half an hour to reduce nonspecific staining. This was followed by incubation with $0 \cdot 2 \%$ hydrogen peroxidase for 15 minutes (both at room temperature) to inhibit endogenous peroxidases. The primary layer antibodies were then added and incubated for one hour at room temperature.

The panel of primary monoclonal antibodies, their specificities and the dilutions used were as follows:

(a) Murine monoclonal anti-human IL-6 antibody (Serotec, MCA 746) at 1:50 dilution. This recognises human IL-6 and has no cross reactivity with TNF- $\alpha$ or interleukin 1 .

(b) Murine monoclonal anti-human TNF$\alpha$ antibody (Serotec, MCA 747) at 1:50 dilution. This recognises human TNF- $\alpha$ but not TNF $\beta$, IL-6, or interleukin 1.

(c) Murine monoclonal anti-human CD45 antibody (Serotec, MCA 669) at 1:80 dilution. This recognises the common leukocyte antigen but not haematopoeitic cells and gives an estimate of the total inflammatory infiltrate.

(d) Murine monoclonal anti-human CD68 (Serotec, MCA 759) at 1:100 dilution. This recognises a monocyte and macrophage surface antigen, the cell type which is the predominant secretor of IL-6 and TNF- $\alpha$. It is absent on other leukocytes.

The second layer antibody used was biotinylated rabbit anti-mouse immunoglobulin (Dako, Z109), diluted at 1:300 and incubated for 30 minutes. Incubation with streptavidinbiotin complex (Dako, K391), diluted 1:100 for 30 minutes then, 3,3'-Diaminobenzidine tetrahydrochloride for 15 minutes to develop the peroxidase was followed by thorough washing and counterstaining with haematoxylin. After each of the above steps sections were thoroughly washed in Tris buffered saline for 10 minutes (with three changes of solution).

\section{CONTROLS}

The staining of sections obtained from human tonsil with anti-human IL-6 and TNF- $\alpha$ monoclonal antibodies and staining of small intestine with murine anti-human CD45 (panleukocyte antigen, Serotec) at 1:80 dilution served as positive controls. The omission of the primary incubating antibody served as a negative control.

\section{COUNTING OF SECTIONS}

Quantification of positively stained cells was achieved in the lamina propria by using a calibrated eyepiece graticule in a Leitz Westlar microscope at $\times 400$ magnification, the graticule represented $0.0025 \mathrm{~mm}^{2}$ in area. At least three complete villi (assessed superficially from the tip of the villus directly down to the deep lamina propria) were counted and results expressed as the mean number of positive staining cells per unit area of the lamina propria. Positive cells in the epithelium were expressed relative to 100 epithelial cells per section $^{19}$ and at least 500 epithelial cells were counted per section. Slides were counted by two independent observers and interobserver results varied by less than $10 \%$.

\section{STATISTICAL ANALYSIS}

This was performed using non-parametric methods. Results for each group of patients were expressed as a median value with the interquartile range shown in brackets where appropriate. Differences between groups were calculated using the Wilcoxon rank sum test for differences between unpaired data. A difference was considered to be significant if $\mathrm{p}<0.05$.

\section{Results}

LAMINA PROPRIA

The Table shows that the median IL-6 $(16.2 /$ unit area, both $\mathrm{p}<0.05)$ and TNF- $\alpha$ $(13.0 /$ unit area, both $\mathrm{p}<0.05)$ staining was significantly higher in the lamina propria of the

Amount of interleukin-6 (IL-6) and tumour necrosis factor alpha (TNF- $\alpha$ ) in the lamina propria and epithelium of untreated and treated coeliac disease patients and control patients (values, median (interquartile range) number of positively staining cells)

\begin{tabular}{|c|c|c|c|c|}
\hline & $I L-6$ & $T N F-\alpha$ & $C D 68$ & $C D 45$ \\
\hline $\begin{array}{l}\text { Lamina propria (per unit area): } \\
\text { Untreated coeliac disease } \\
\text { Treated coeliac disease } \\
\text { Controls } \\
\text { Epithelium (per } 100 \text { cells): }\end{array}$ & $\begin{array}{c}16 \cdot 2(14 \cdot 5-18 \cdot 3)^{\star} \dagger \\
6 \cdot 0(5 \cdot 8-6 \cdot 6) \\
6 \cdot 5(6 \cdot 2-7 \cdot 5)\end{array}$ & $\begin{array}{l}13 \cdot 0(11 \cdot 6-15 \cdot 2)^{\star} \dagger \\
6 \cdot 2(5 \cdot 9-7 \cdot 1) \\
7 \cdot 5(5 \cdot 7-8 \cdot 3)\end{array}$ & $\begin{array}{l}36 \cdot 7(32 \cdot 0-40 \cdot 7)^{\star} \dagger \\
16 \cdot 5(15 \cdot 0-21 \cdot 3) \\
11 \cdot 4(11 \cdot 0-15 \cdot 5)\end{array}$ & $\begin{array}{c}104 \cdot 0(96 \cdot 3-120) \star \\
49 \cdot 3(40 \cdot 3-56 \cdot 3) \\
41 \cdot 3(39 \cdot 3-45 \cdot 7)\end{array}$ \\
\hline $\begin{array}{l}\text { Untreated coeliac disease } \\
\text { Treated coeliac disease } \\
\text { Controls }\end{array}$ & $\begin{array}{l}0.86(0.36-1.20)^{\star} \dagger \\
0.60(0.03-0.61) \\
0.58(0.04-0.60)\end{array}$ & $\begin{array}{l}1.21(0.44-1.26)^{\star} \dagger \\
0.60(0.02-0.60) \\
0.60(0.04-0.60)\end{array}$ & $\begin{array}{l}8 \cdot 2(5 \cdot 8-10 \cdot 0) \\
6 \cdot 4(5 \cdot 5-8 \cdot 0) \\
6 \cdot 0(4 \cdot 0-6 \cdot 3)\end{array}$ & $\begin{array}{l}96 \cdot 6(66 \cdot 5-100 \cdot 0)^{\star} \\
83 \cdot 3(66 \cdot 0-85 \cdot 0)^{\star} \\
62 \cdot 1(34 \cdot 0-72 \cdot 0)\end{array}$ \\
\hline
\end{tabular}

$\star$ Denotes $\mathrm{p}<0.05$ compared with the control group. †Denotes $\mathrm{p}<0.05$ compared with treated coeliac disease group. 


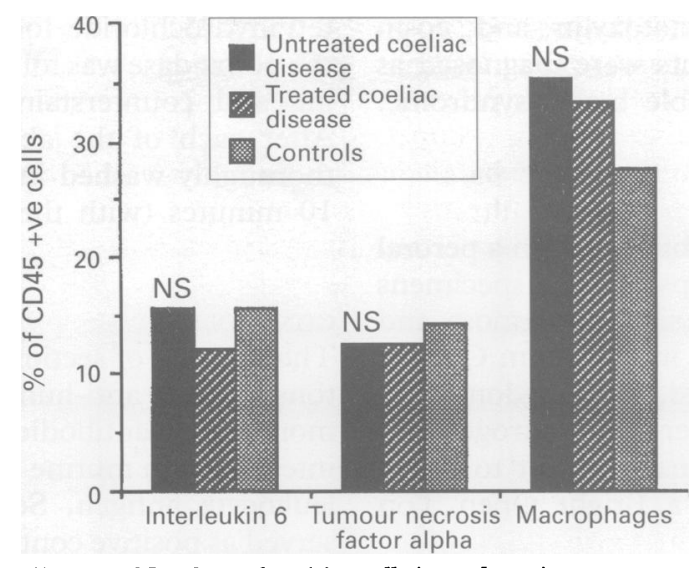

Figure 1: Numbers of positive cells in each patient group expressed as a percentage of the total white cell count (CD45) in the lamina propria. (The histogram shows that the percentage of interleukin 6, tumour necrosis factor alpha, and CD68 within the total white cell population remains constant within all three groups of patients.)

untreated coeliac disease group than in the treated coeliac (6.0/unit area and 6.2/unit area respectively) control groups (6.5/unit area and $7 \cdot 5 /$ unit area respectively). In untreated coeliac disease we observed a significantly increased number of CD45 staining cells representing the total inflammatory infiltrate (median; 104.0 /unit area, $\mathrm{p}<0.01$ ) when compared with both the treated coeliac group (49.3/unit area) and disease controls (41.3/unit area). The number of macrophages was also significantly increased in the lamina propria of the untreated coeliac disease patients compared with the treated coeliac and control groups (36.7/unit area $v 16 \cdot 5 /$ unit area and $11 \cdot 4 /$ unit area respectively, both $\mathrm{p}<0.05)$.

There was no difference in the percentage of IL-6, TNF- $\alpha$ staining cells or macrophages within the total white cell count as assessed by the number of CD45 positive cells (see Fig 1).

\section{EPITHELIUM}

The Table shows that there was a significantly greater median IL-6 and TNF- $\alpha$ staining on

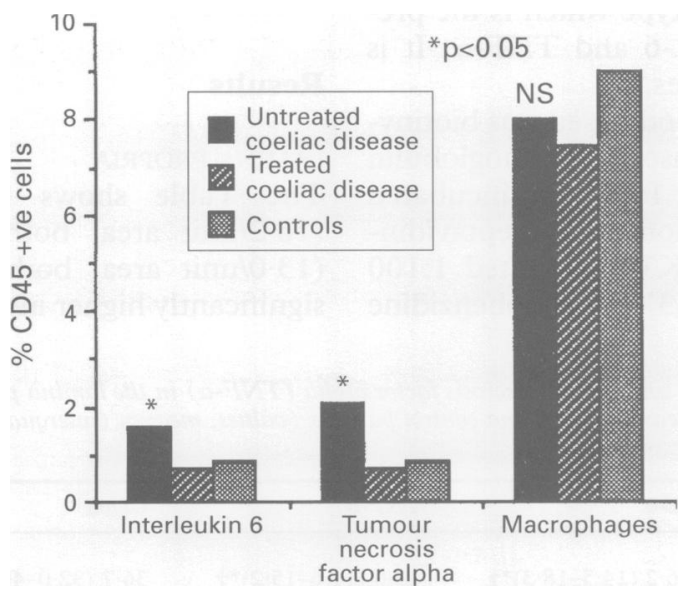

Figure 2: Staining of cytokines expressed as the percentage of CD45 in the epithelium of the three patient groups. (The histogram shows a significantly increased percentage of CD45 made up of interleukin 6 and tumour necrosis factor alpha positive cells in untreated coeliac disease epithelium. Despite this the percentage stained in each of the three patient groups was very small.) cells within the epithelium in the untreated coeliac disease group than in the treated coeliac disease and disease control groups $(p=0.05$ for each). The median percentage of CD45 cells that stained positive for these cytokines was also significantly higher in untreated coeliac disease $(1 \cdot 6 \%$ and $2 \cdot 1 \%$ respectively, $\mathrm{p}<0.05$ in each case) compared with treated coeliac disease $(0.7 \%$ and $0.7 \%$ respectively) and the control group (0.9\% and $0.8 \%$ respectively) (see Fig 2 ). There were significantly more CD45 positive cells in the untreated coeliac disease patients than in controls $(p=0.048)$ but there was no significant difference between untreated and treated coeliac disease $(p=0 \cdot 234)$. There was no significant difference in the low numbers of epithelial macrophages between the three groups, suggesting that the cytokines may be secreted by another cell type in this compartment. In four patients with untreated coeliac disease very little staining .was found in this compartment $(0.0$ and $0.02,0.03$ and 0.08 , 0.06 and $0.06,0.10$ and $0.36 / 100$ epithelial cells for IL-6 and TNF- $\alpha$ respectively) despite histological evidence of villous flattening and an excess of these cytokines within the lamina propria. Therefore, in the epithelial compartment there was a significant increase in the small number of cells staining for both cytokines in untreated coeliac disease. The percentage of the total inflammatory infiltrate involved in their secretion was numerically much smaller than in the lamina propria but also significantly raised in the untreated group.

\section{Discussion}

There is increasing evidence to support the hypothesis that the lesion seen in coeliac disease is caused by the activation of a cell mediated immune response secondary to the ingestion of dietary gluten. It is thought that in coeliac disease the antigenic peptide within gluten is presented in association with HLA DQ2 molecules on the surface of intestinal macrophages and that this 'complex' is recognised by gliadin antigen sensitive $\mathrm{T}$ lymphocytes in the lamina propria of the small intestine. Their activation results in the release of mediators including an abnormal profile of proinflammatory cytokines, recruitment of inflammatory cells including macrophages, and propagation of the inflammatory process. The observed mucosal damage may be caused by the non-specific release of large amounts of cytotoxic factors including IL- 6 and TNF- $\alpha$ from these cells. When studying the mucosal immunology of coeliac disease it is therefore important to consider any changes in the lamina propria and epithelium separately which we have done.

In this study we have shown a significant increase in the median number of cells staining positive for the cytokines IL- 6 and TNF- $\alpha$, both in the lamina propria and in the epithelium of inflamed coeliac jejunal mucosa. These amounts were significantly greater than those found in patients treated with a gluten free diet 
and in the control group. The percentage of cells staining positive for these cytokines within the white cell infiltrate of the lamina propria did not differ between the three patient groups and this could be explained by the parallel increase in the total number of infiltrating (non-IL-6 and TNF- $\alpha$ producing) leukocytes here.

The percentage of the total leukocyte count that stained positive for each cytokine was significantly increased in the epithelium of the untreated coeliac disease group. Despite the significant increase in staining and the percentage of positive cells in the epithelium of the untreated coeliac group, the numbers of cells counted in four of the 11 untreated coeliac disease patients were very small or absent (see results) despite the presence of an avillous mucosa and excess staining in the lamina propria. These cells represented only a small percentage of the epithelial total white cell count in the untreated coeliac disease group ( $1 \cdot 6 \%$ for IL- 6 and $2 \cdot 1 \%$ for TNF- $\alpha$ ). This suggests that epithelial cytokine production may not be as important in the pathogenesis of the disease as that in the lamina propria. Our findings differ from previous reports suggesting that the production of IL-6 is localised mainly in the epithelium of the large and small intestine. ${ }^{20}$

The patients in our study had the fully developed lesion of coeliac disease and more subtle information on the site and kinetics of cytokine secretion could be obtained by studying early jejunal biopsy specimens taken after a gluten challenge in treated coeliac patients. In untreated coeliac disease the increase in inflammatory cell infiltrate within the lamina propria consists predominantly of $\mathrm{T}$ lymphocytes and macrophages. ${ }^{21} \mathrm{We}$ found a significantly increased number of leukocytes and macrophages within the lamina propria of the untreated coeliac disease group. The latter are thought to be the main source of IL-6 and TNF- $\alpha$ in this tissue. ${ }^{722}$

There was no change in the number of epithelial macrophages present in each of the three patient groups. In coeliac disease the epithelium contains an increased number of $\gamma / \delta$ T lymphocytes. ${ }^{23} 24$ It may be that stimulation of these cells, whose function is unclear, or those with an $\alpha / \beta$ receptor and CD8 positive subtype may be responsible for the secretion of some cytokines here. ${ }^{25} 26$ Alternatively, these epithelial cytokines may originate from another source such as mast cells ${ }^{27}$ or diffuse into the epithelium from the lamina propria. A number of different cells can be induced to secrete both of these cytokines and it would be interesting to extend our work using a double staining immunohistochemical technique or one combining specific cytokine RNA analysis and immunohistochemistry to identify these better.

The limitations of staining for cytokines by immunohistochemistry are worth noting and must be allowed for when drawing conclusions from these studies. Identifiable protein is affected by natural cytokine inhibitors and also in some cases by well defined soluble receptors and receptor antagonists. ${ }^{28}$ Counting of tissue

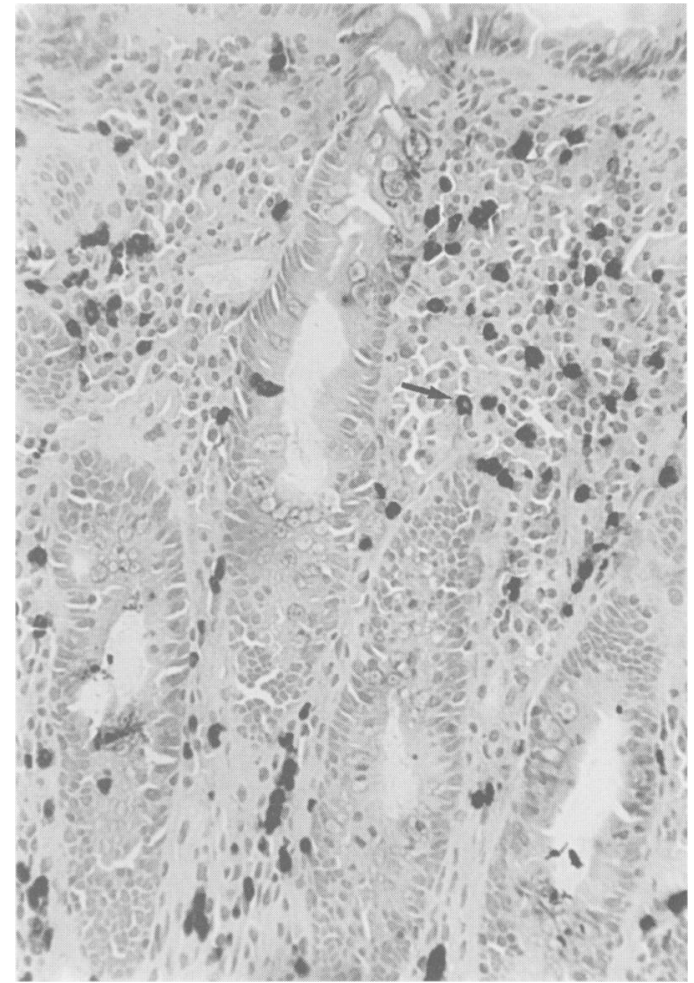

Figure 3: Staining of untreated coeliac mucosa with anti-tumour necrosis factor alpha monoclonal antibody. Showing numerous positively staining cells (arrowed) throughout the lamina propria and, to a lesser degree, in the epithelium.

needs to be standardised and reproducibility of results checked by a second observer. Background staining is inevitable due to the passive uptake of protein by some cells and the staining of secreted extracellular protein, although this can be reduced by careful titration of primary antibody and thorough washing of sections. We found that careful washing and inhibition of endogenous peroxidase eliminated most of the background staining; however, some staining still occurred in negative control section tissue, a problem which others have encountered ${ }^{29}$ but which we were able to overcome as the staining was light and limited to goblet cells and intercellular matrix and hence easily distinguishable (see Figs 3-5). Despite these difficulties the technique allows the identification of biologically active genetic product within tissues. The analysis of cytokine mRNA can be used to verify the results obtained but it has previously been demonstrated that not all mRNA motifs are necessarily translated into active protein. ${ }^{30} \mathrm{We}$ have found close correlation of our results with those obtained by the analysis of IL- 6 and TNF- $\alpha$ mRNA using a radioactive, in situ hybridisation technique thus supporting our immunohistochemical findings. ${ }^{31}$ This shows the desirability of studies into cytokine protein to include some assessment of cytokine mRNA production and to correlate the results obtained with those of protein analysis.

Although isolated changes in individual cytokines are unlikely to explain entirely the pathological picture seen in coeliac disease, ${ }^{32}$ the finding of raised IL- 6 and TNF- $\alpha$ cell concentrations is highly relevant, knowing their well defined individual effects on intestinal 


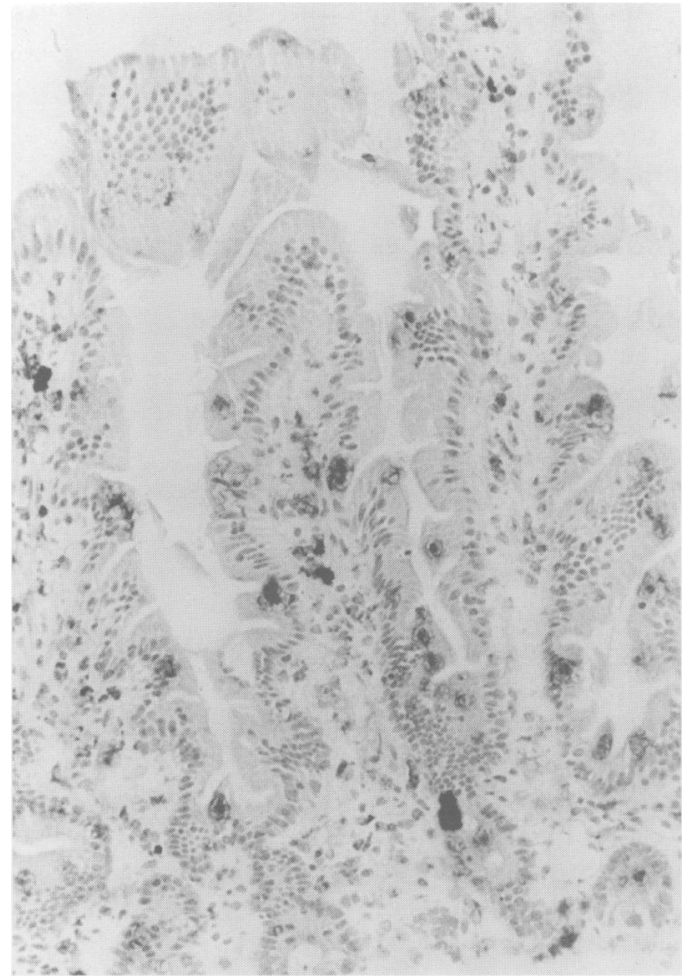

Figure 4: Staining shows a marked reduction in the amount of tumour necrosis factor alpha in the mucosa of a patient treated with a gluten free diet.

tissue. It is likely therefore that increased production of these cytokines, especially in the lamina propria is important in the immune pathogenesis of this disorder and our findings lend further support to the existing evidence implicating cell mediated immunity in the pathogenesis of this disease.

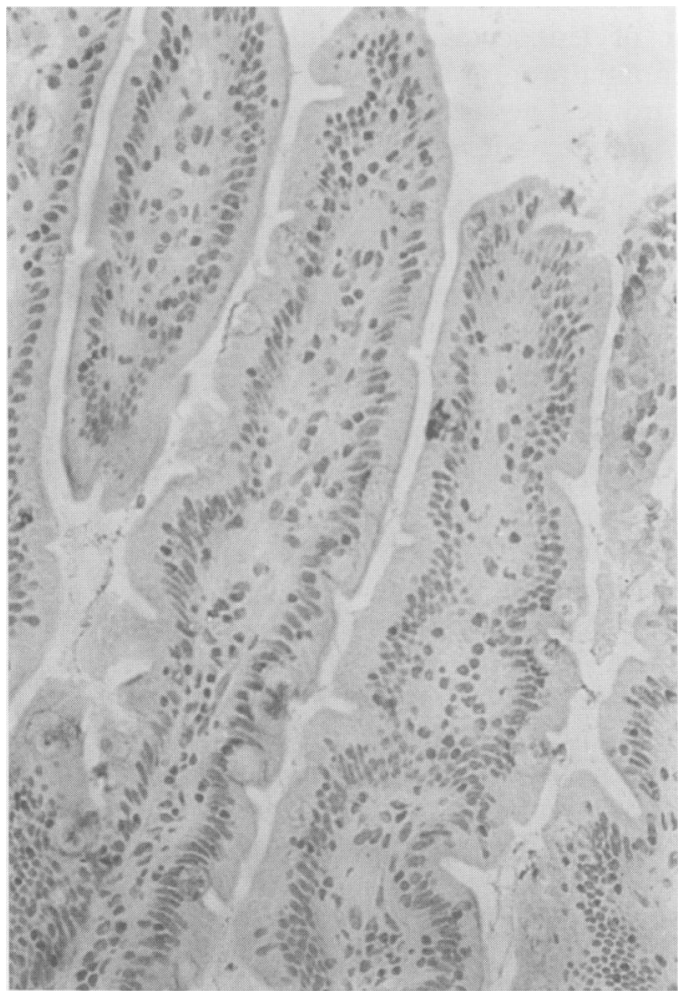

Figure 5: A negative control slide demonstrating some residual staining. However, this is easily identifiable and except for that associated with goblet cells is clearly non-cellular in its association.
A better understanding of the molecular events which initiate and drive the inflammatory response in coeliac disease may be of help in the development of more effective treatments in other inflammatory bowel conditions in which cytokines are also thought to be of importance in the development of the mucosal lesion but in which the causal agents are not known. 3334

The authors thank Mr J Nelufer for technical assistance, the St Thomas's Hospital Research (Endowments) Committee, the Institute of Paediatrics 'La Sapienza', University of Rome, and the Jean Shank Research Foundation for financial support.

1 Marsh MN. Immunocytes, enterocytes and the lamina propria, an immunopathologic framework of coeliac disease. F R Coll Physicians Lond 1983; 17: 205-12.

2 Ferguson A, Parrott DMV. Histopathology and time course of rejection of allografts of small mouse intestine. Transplantation 1973; 15: 546-54.

3 Ferguson A. Models of immunologically-driven small intestinal damage. In: Marsh MN, ed. Immunopathology of the small intestine. Chichester: John Wiley, 1987: 225-32.

4 Lundin $\mathrm{K}$, Scott $\mathrm{H}$, Hansen $\mathrm{T}$, Paulsen G, Halstensen T, Fausa O, et al. Gliadin-specific, HLA-DQ ( $\alpha 1^{\star} 0501$, $\left.\beta 1^{\star} 0201\right)$ restricted T cells isolated from the small intestinal mucosa of celiac disease patients. $₹$ Exp Med 1993; 178: $187-96$.

5 MacDonald TT. T-cell mediated intestinal injury. In: Marsh MN, ed. Coeliac disease. Oxford, UK: Blackwell Scientific Publications, 1993: 283-304.

6 Brantzaeg P. Immunological basis for coeliac disease, inflammatory bowel disease and type B chronic gastritis. Current Opinion in Gastroenterology 1991; 7: 450.

7 Akira S, Hirano T, Taga T, Kishimoto T. Biology of multifunctional cytokines IL6 and related molecules. FASEB 1990; 4: 2860-7.

8 Poli V, Cortese R. Interleukin 6 induces a liver specific nuclear protein that binds to the promotor of acute phase genes. Proc Natl Acad Sci (USA) 1989; 86: 8202.

9 Taga T, Kawanishi Y, Hardy R, Hirano T, Kishimoto T. Receptors for B cell stimulatory factor 2. Quantitation, specificity, distribution and regulation of their expression. f Exp Med 1987; 166: 967

10 Tosato G, Seamon K, Goldman N, Sehgal P, May L, Washington, $\mathrm{G}$, et al. Monocyte derived human B-cell growth factor identified as interferon-beta 2 (BSF-2, IL6) Science 1988; 239: 502-4.

11 Taga T, Kishimoto T. In: Human cytokines. Oxford: Blackwell Scientific Publications, 1992: 143.

12 Sturgess R, Hooper L, Spencer J, Hung C-H, Nelufer J, Ciclitira PJ. Effects of interferon- $\gamma$ and tumour necrosis factor- $\alpha$ on epithelial HLA class II expression on jejunal mucosal biopsy specimens cultured 'in vitro'. Scand $f$ mucosal biopsy specimens cultured

13 Gamble JR, Harlan JM, Klebnoff SJ, Vaclas MA Stimulation of the adherence of neutrophils to umbilical Stimulation of the adherence of neutrophils to umbilical
vein endothelium by human recombinant tumour necrosis vein endothelium by human recombinant tumour necro

14 Ming WJ, Bersani L, Mantovani A. Tumour necrosis factor is chemotactic for monocytes and polymorphonuclear leucocytes. F Immunol 1987; 138: 1469-74.

15 Yokota T, Geppert TD, Lipsky PE. Enhancement of antigen and mitogen induced human T-lymphocyte proliferation by tumor necrosis factor alpha. F Immunol 1988; 140: 531-6.

16 Pober jS. Cytokine mediated activation of vascular endothelium, physiology and pathology. Am $f$ Pathol endothelium, physiolc

17 Yamauchi N, Kuriyama H, Watanabe N, Neda H, Maeda $M$, Niitsu $\mathrm{Y}$, et al. Intracellular hydroxyl radical production induced by recombinant human tumor necrosis tion induced by recombinant human tumor necrosis

18 Walker-Smith J, Guandalini S, Schmitz J, Schmerling D, $\mathbb{D}$ Visakorpi J. Revised criteria for diagnosis of coeliac disease. Arch Dis Child 1990; 65: 909-11.

19 Ferguson A, MacDonald TT, McClure JP, Holden RJ. Quantitation of intraepithelial lymphocytes in human jejunum. Gut 1971; 12: 988-94.

20 Shirota K, LeDuy I, Yuan S, Jothy S. Interleukin 6 and its receptor are expressed in human intestinal epithelial cells.

21 Pink IJ, Creamer B. Response to a gluten free diet of patients with coeliac syndrome. Lancet 1967; i: 300-4. 22 Talmadge JE, Phillips H, Schneider M, Rowe T, Pennington $\mathrm{R}$, Bowersox $\mathrm{O}$, et al. Immunomodulatory properties of recombinant murine and human tumor necrosis factor. Cancer Res 1989; 1:48 (3): 544-50.

23 Viney J, MacDonald TT, Spencer J. Gamma/delta T-cells in the gut epithelium. Gut 1990; 31: 841-4.

24 Sturgess R, Kontakou M, Nelufer J, Hung T, Ciclitira P. $\gamma / \delta$ $\mathrm{T}$-cell receptor expression in the jejunal epithelium of patients with dermatitis herpetiformis and coeliac disease. Clin Exp Dermatol 1993; 18: 318-21.

25 Christmas SE. Cytokine production by T-lymphocytes bearing the gamma-delta $\mathrm{T}$-cell antigen receptor. Chem Immunol 1992; 53: 32-46. 
26 Leung JC, Lai CK, Chui YL, Ho RT, Lui KN. Charachterisation of cytokine gene expression in $\mathrm{CD} 4+$ and $\mathrm{CD} 8+\mathrm{T}$-cells after activation with phorbol myrisate acetate and PHA. Clin Exp Immunol 1992; 90 (1): $147-53$.

27 Gordon JR, Galli SJ. Mast cells as a source of both preGordon JR, Galli SJ. Mast cells as a source of both pre-
formed and immunologically active TNF alpha/cachectin. Nature 1990; 346 (6281): 274-6.

28 Arrend W, Dayer J. Cytokines and cytokine inhibitors or antagonists in rheumatoid arthritis. Arthritis Rheum 1990; 33: 305-15.

29 Murch SH, Braegger CP, Walker-Smith JA, MacDonald TT. Location of tumour necrosis factor $\alpha$ by immunohistochemistry in chronic inflammatory bowel disease. Gut 1993; 34 (12): 1705-9.

30 Butler B, Krochin N, Milsark I, Luedke C, Cerami A.
Control of cachectin (tumor necrosis factor) synthesis: Mechanisms of endotoxin resistance. Science 1986; 232 (4753): 977-80

31 Przemioslo RT, Kontakou $M$, Nobili V, Sturgess R, Ciclitira PJ. Interleukin-6 and tumour necrosis factor- $\alpha$ in coeliac disease mucosa detected by immunohistochemical and in-situ hybridisation. Gut 1993; 34: S4:T94.

32 Balkwill F. Cytokines in health and disease. Immunol Today 1993; 14: 4: 149-50.

33 Pullman WE, Elsbury S, Kobayashi M, Hapel AJ, Doe WF. Enhanced mucosal cytokine production in inflammatory bowel disease. Gastroenterology 1992; 102: 529-37.

34 Stevens C, Walz G, Singaram C, et al. Tumor necrosis factor- $\alpha$, interleukin- 1 beta and interleukin- 6 expression in inflammatory bowel disease. Dig Dis Sci 1992; 37: 818-26. 